\title{
An explanatory analysis to identify and prioritize the challenges of Islamic Banking implementation: the case of I.R. Iran
}

\author{
Seyed Reza Seyed-Javadin, Reza Raei, Mohammad Javad Iravani, \\ Mohammad Safari* \\ ${ }^{1}$ Faculty of Management, University of Tehran, Tehran, Iran \\ *E-mail address: m.safari@ut.ac.ir
}

\begin{abstract}
Islamic banking system has emerged as a competitive and a viable substitute for the conventional banking system during the last four decades. Islamic banking is a banking activity that is accordance with the laws of Islam (Islamic jurisprudence) and its practical application is in the development of Islamic economics. For complete implementation of Islamic banking, namely transition from interest free banking system and going forward to reach the total Islamic banking system, there are challenges and problems involved. The main purpose of this research is to identify and explain the important challenges associated with IB implementation in I.R.Iran. To achieve this goal, based on the qualitative method after a detailed study of the theoretical foundation and literature review, using data obtained from interviews with experts and the convenient questionnaire, the final identified factors have been analyzed and presented in form of a conceptual research model. Experts of this research were both academicians and practitioners in the field of banking and financial system. The findings showed that significant challenges exist to establish a comprehensive system of Islamic banking; accordingly policy makers and mangers in order to succeed in this system should consider them. The convenient programs should be settled so that the problems and challenges eliminated and the road to success implementation will be paved.
\end{abstract}

Keywords: Islamic banking; banking sector; challenges; explanation; Iran

\section{INTRODUCTION}

Banks as the most important financial institution in money market and also the largest financial intermediaries in the economy (Mishkin, 2004: 8), received the deposits of depositors and instead pay loans and facilities to applicants and give interest (Frost, 2004: 14). In Islamic economics this role while maintaining the principles of Shariah has been granted to Islamic banks (Mousavian, 2002: 3). The origin of Shariah (Islamic Law) rulings on how Muslims should conduct their economic and financial affairs are as old as Islamic itself. However, the modern history of Islamic banking can be traced back to 1960s. It was not until last decade that Islamic banking emerged as an established player on financial scene. Middle East and Malaysia remains hub of Islamic finance though most important development is emergence of non-Muslim countries as powerful centers of Islamic banking and finance (Malik, 2011). Islamic banking as an important innovation in the second half of the twentieth 
century in Muslim countries rejected the conventional banking and suggested a new paradigm. Before the introduction of Islamic Banking, all the Muslim customers had to rely on the conventional banking practices. These banks products were no way near to the principles of Islam as the conventional banking products revolve around the earnings of interest (Riba) which is clearly prohibited in Islam (Malik, 2011).

The Quran, the Muslims' holy book, explicitly deals with economic-related matters and how they apply in Islam. The Shariah, this being the Islamic law of human conduct, is derived from the Quran. The Shariah prohibits what is called Riba (i.e. payment over and above what has been lent, which causes the payment of interest or usury to be a wrong). What the Shariah (Islamic jurisprudence) does not prohibit is profit acquired from a trading activity, the reasoning behind this positive stance being that there is a risk of loss involved in any trading activity. With Riba, in theory, there is no risk of loss (Gerrard and Cunningham, 1997). Because of Riba, Islamic banks have had to develop financial products which are not in conflict with the Shariah. This has resulted in traditional deposit and lending products, which are made available by what can be called conventional banks, being restyled so as to satisfy the Shariah (Gerrard and Cunningham, 1997). Islamic banking is an economic and financial framework which is based upon the principles of Islamic Laws also known as Shariah Laws. It's a system of banking which is in accordance with the principles of Islamic law and Shariah. Shariah law prohibits the acceptance or giving interest on the money borrowed or lent which is commonly known as Riba. (Iqbal and Molyneux, 2005). Islamic banking and finance now is the strong industry in the Islamic and Western markets, but will continue to face struggles in the process. Unlike conventional finance, the success of Islamic finance depends on both satisfying faith and economics (Malik, 2011). Therefore, the main purpose of this research is to identify and explain the important challenges associated with IB implementation in I.R.Iran. Accordingly the basic research question is: what are the main challenges of Islamic banking implementation in Iran?

\section{LITERATURE REVIEW}

Approximately 1.57 billion individuals -nearly 1 in 4 people- in the world are Muslims according to the 2009 Pew Forum on Religion and Public Life report ${ }^{1}$. The Islamic banking and finance industry has grown substantially worldwide. Fundamental essence of Islamic banking system is based on the fact that although Islam has forbidden interest in transactions but trade and profit is encouraged and supported (Gudarzi et al, 2013). A unique feature of Islamic banking, in theory, is its profit-and-loss sharing (PLS) paradigm (Chong and Liu, 2009). Islamic banking refers to a system of banking or banking activity that is consistent with the Principles of Islamic Law (Shariah and Islamic jurisprudence). Shariah prohibits the practice of giving or accepting additional money for money that is borrowed. In other words, Shariah bans interest charged on loans, regardless of the quantum of the interest. Furthermore, the types of businesses must also comply with the principles of Islam. Since Islam prohibits Usury, sharing the risk of trading and investment is aligned with the principle of Islam. This means that the moneylender has to take a risk by participating in the business of the moneyborrower. In other words, in Islam the relationship between the borrower and the lender is more than a purely creditor-debtor relationship. Essentially, Islam encourages businesses to

\footnotetext{
${ }^{1}$. Adapted from: http://www.emeraldinsight.com
} 
grow by taking risk and taking part in a project without compromising the welfare of either party (Kamarulzaman and Madun, 2013).

An Islamic banking and financial system exists to provide a variety of religiously acceptable financial services to the Muslim communities. In addition to this special function, the banking and financial institutions, like all other aspects of Islamic society, are expected to contribute richly to the achievement of the major socio-economic goals of Islam (Chapra, 1985). The most important of these are economic well-being with full employment and a high rate of economic growth, socioeconomic justice and an equitable distribution of income and wealth, stability in the value of money, and the mobilization and investment of savings for economic development in such a way that a just (profit sharing) return is ensured to all parties involved. Perhaps the religious dimension should be presented as a further explicit goal, in the sense that the opportunity to conduct religiously legitimate financial operations has a value far beyond that of the mode of the financial operation itself (Hassan and Lewis, 2007).

Islamic banking comprehensive model not only seeks to eliminate usury from the transactions, but also operates and execute other Islamic teachings in the areas of banking and finance efficiently and effectively. Indeed, the desired framework for Islamic banking is the final or ultimate mode for this system and interest free framework is the transient state. The Iran's banking system after the approval of interest-free banking law in 1983 and its implementation since 1984 due to differences with the interest-based banking has faced the challenges. One of these challenges is profit rate of granted facilities in exchange contracts (Dadgar and Firouzan, 2012).

\section{PREVIOUS RESEARCH}

In this section of the paper, based on a detailed study of previous research, in form of Table 1, the major findings of previous researches related to the current study are presented and discussed. In this section tried to provide the most recent findings and related studies along with useful and convenient contributions.

Table 1. Significant researches and studies related to the research background.

\begin{tabular}{lcl}
\hline Scholars/Researchers & Year & Contributions and findings \\
\hline $\begin{array}{l}\text { Mat Rahim, S.R. and Zakaria, } 2013 \\
\text { R.H. }\end{array}$ & $\begin{array}{l}\text { Using analytical method this research investigated the } \\
\text { comparison on stability between Islamic and conventional } \\
\text { banks focusing on the Malaysian banks. Results illustrated } \\
\text { that the average Islamic banks are relatively more stable } \\
\text { than their conventional counterparts. }\end{array}$ \\
Shaikh, S.A. 2013 & $\begin{array}{l}\text { This research study using critical analysis mainly focused } \\
\text { on Pakistan Islamic banking. Also, investigated and } \\
\text { analysed the foundations of Islamic and conventional } \\
\text { banking systems with applications in Pakistan. }\end{array}$ \\
Shah, S.F.; Raza, M.W. and 2012 & $\begin{array}{l}\text { This paper basically examined and explored the different } \\
\text { controversies which are in the minds of people which need } \\
\text { to be addressed. Also has been tried to suggest suitable } \\
\text { solutions to overcome these challenges and controversies. } \\
\text { The study investigated the users perceptions of Islamic } \\
\text { banking practices in the United Kingdom. The overall }\end{array}$ \\
Akbar, S.; Shah, S.A. and & 2012 &
\end{tabular}




\begin{tabular}{|c|c|c|}
\hline Scholars/Researchers & Year & Contributions and findings \\
\hline & & $\begin{array}{l}\text { findings of this study suggested that Islamic banking in the } \\
\text { UK is not fully aligned with the paradigm version of } \\
\text { Islamic finance. The customers generally agree with the } \\
\text { view that the principle of profit and loss sharing element } \\
\text { represents the true spirit of Islamic banking practices. There } \\
\text { was a high expectation among the customers about the } \\
\text { commitment and strong welfare role of Islamic banks in } \\
\text { society. }\end{array}$ \\
\hline
\end{tabular}

Sole, J.

Iqbal, Z.

Mirakhor, A.

Siddiqi, M.N.

Karbhari, Y.; Naser, K. and

Shahin, Z.

Zaher, T.S. and Hassan, M.K.
2008

paper attempted to describe some light in this area by describing the main phases in the process, and by flagging some of the main challenges that countries will face as Islamic banking develops alongside conventional institutions.

2007 The author discussed the challenges facing the Islamic financial services industry. This research identify 4 certain areas that deserve immediate attention, these areas are: a) Financial Engineering, b) Risk Management and Diversification, c) Non-Bank Financial Services, and d) Development of Capital Markets.

2007 The study explored the potential convergence of Islamic and conventional finance as these systems continue their progress in designing and developing better risk-sharing structure and much expanded menu of financial instruments. It discussed the legal, institutional, governance, and financial preconditions that should exist for equity finance to dominate debt financing.

2006 The study explained the theoretical foundations of the Islamic banking system in Islamic society, and also the basic reasons toward formation of this system and some of its functions have been described.

2004 This study investigated the main problems, challenges, and opportunities facing Islamic banking system especially with focus on the United Kingdom. Thus the main contribution of this research was to provide empirical evidence on problems facing the Islamic banking in the West, with the UK as a case study.

2002 This research provided a comprehensive comparative review of the literature on the Islamic financial system. Specifically, discussed the basic features of the Islamic finance and banking. Also an empirical assessment of the performance of Islamic banking and finance, and highlights the regulations, challenges and problems in the Islamic banking market have been presented.

Wilson, R.

2000 Using British market for Islamic banking and financial services, the research analysed the challenges and opportunities facing Islamic Banking and Finance in the West; especially focused on the United Kingdom 


\begin{tabular}{lcl}
\hline Scholars/Researchers & Year & Contributions and findings \\
\hline Abdullah, F. and Iqbal, M. 1999 & $\begin{array}{l}\text { Experience. } \\
\text { The study Presented some major challenges facing Islamic } \\
\text { banking in the } 21^{\text {st }} \text { Century. }\end{array}$ \\
Iqbal, Z. and Mirakhor, A. 1999 & $\begin{array}{l}\text { The research investigated and explained the main } \\
\text { progresses and also challenges and problems associated } \\
\text { with the field of Islamic banking and finance. } \\
\text { Iqbal, M.; Ahmad, A. and } \\
\text { Khan, T. }\end{array}$ \\
& $1998 \begin{array}{l}\text { The study attempted to analysis the challenges confronting } \\
\text { the Islamic banking in both institutional and operational } \\
\text { aspects respectively. }\end{array}$ \\
\hline
\end{tabular}

\section{METHODOLOGY}

Using a qualitative approach in the form of in-depth interviews, in this study attempted to identify and present the important challenges of Islamic banking implementation with focus of Iran. After detailed literature review and studding the previous researches using interviews with experts and also by means of relevant and appropriate questionnaire, required data was gathered and then analyzed. Using interviews and questionnaire together makes the better and more practical data for a research and accordingly deeper and most related analyses is provided. Research's experts were including 20 persons both in mangers and practitioners involved in banking system and scholars and academic experts of the field. After finalizing factors obtained in the research, using relevant statistical tests and appropriate descriptive figures and tables, necessary and required analyzes were performed and results were be provided. In order to measure effects of factors identified in the study, the one-sample t-test has been used; also for ranking or prioritizing the factors the Friedman test has been exerted.

\section{FINDINGS}

Based on the research design and data gathered that describe in the previous sections, the challenges identified in this section has been provided. Table 2 shows the results of this finding.

Table 2. Findings on the challenges and factors.

\begin{tabular}{ccl}
\hline No. & Indicator & Challenges and factors \\
\hline $\mathbf{1}$ & F1 & Lack of clear rules and adequate supervision \\
$\mathbf{2}$ & F2 & Lack of determination at the senior executives and managers \\
$\mathbf{3}$ & F3 & Lack of sufficient awareness among customers and people \\
$\mathbf{4}$ & F4 & The lack of failure to comply with the new financial system \\
$\mathbf{5}$ & F5 & Lack of competitiveness with conventional banking system \\
$\mathbf{6}$ & F6 & Investors' risk aversion and the desire to get a fixed profit \\
\hline
\end{tabular}




\begin{tabular}{ccl}
\hline $\mathbf{7}$ & F7 & Lack of variety for different investors' preferences \\
$\mathbf{8}$ & F8 & Lack of variety for different facilities applicants \\
$\mathbf{9}$ & F9 & Lack of appropriate solutions for banking deferred \\
$\mathbf{1 0}$ & F10 & The lack of international banking interactions \\
\hline
\end{tabular}

In order to analysis the factors identified and provided in this study, in this section for measuring the effects of factors the one-sample t-test has been exerted. Table 3 and 4 show the related results.

Table 3. Results of analysis on statistics.

\begin{tabular}{lcccc}
\hline \multicolumn{1}{c}{ Identified challenges and factors } & $\mathrm{N}$ & Mean & $\begin{array}{c}\text { Std. } \\
\text { Deviation }\end{array}$ & $\begin{array}{c}\text { Std. Error } \\
\text { Mean }\end{array}$ \\
\hline $\begin{array}{l}\text { Lack of clear rules and adequate supervision } \\
\begin{array}{l}\text { Lack of determination at the senior executives } \\
\text { and managers }\end{array}\end{array}$ & 20 & 6.5000 & .94591 & .21151 \\
$\begin{array}{l}\text { Lack of sufficient awareness among customers } \\
\text { and people }\end{array}$ & 20 & 5.8000 & 1.10501 & .24709 \\
$\begin{array}{l}\text { The lack of failure to comply with the new } \\
\text { financial system }\end{array}$ & 20 & 5.5000 & 1.10024 & .24602 \\
$\begin{array}{l}\text { Lack of competitiveness with conventional } \\
\text { banking system }\end{array}$ & 20 & 6.3000 & .92338 & .20647 \\
$\begin{array}{l}\text { Investors' risk aversion and the desire to get a } \\
\text { fixed profit }\end{array}$ & 20 & 6.4500 & .82558 & .18460 \\
$\begin{array}{l}\text { Lack of variety for different investors' } \\
\text { preferences }\end{array}$ & 20 & 6.3500 & .74516 & .16662 \\
$\begin{array}{l}\text { Lack of variety for different facilities applicants } \\
\text { Lack of appropriate solutions for banking }\end{array}$ & 20 & 6.1000 & 1.16529 & .26057 \\
$\begin{array}{l}\text { deferred } \\
\text { The lack of international banking interactions }\end{array}$ & 20 & 6.3500 & .81273 & .18173 \\
\hline
\end{tabular}

Table 4. Results of analysis on One-Sample Test.

\begin{tabular}{|c|c|c|c|c|c|c|}
\hline \multicolumn{7}{|c|}{ Test Value $=4$} \\
\hline \multirow[t]{2}{*}{ 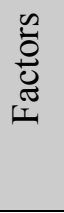 } & \multirow[t]{2}{*}{$\mathrm{t}$} & \multirow[t]{2}{*}{$\mathrm{df}$} & \multirow[t]{2}{*}{$\begin{array}{c}\text { Sig. }^{*} \\
\text { (2-tailed) }\end{array}$} & \multirow{2}{*}{$\begin{array}{c}\text { Mean } \\
\text { Difference }\end{array}$} & \multicolumn{2}{|c|}{$\begin{array}{l}99 \% \text { Confidence Interval of } \\
\text { the Difference }\end{array}$} \\
\hline & & & & & Lower & Upper \\
\hline $\mathrm{F} 1$ & 11.820 & 19 & .000 & 2.50000 & 2.0573 & 2.9427 \\
\hline $\mathrm{F} 2$ & 19.436 & 19 & .000 & 2.60000 & 2.3200 & 2.8800 \\
\hline F3 & 7.285 & 19 & .000 & 1.80000 & 1.2828 & 2.3172 \\
\hline $\mathrm{F} 4$ & 6.097 & 19 & .000 & 1.50000 & .9851 & 2.0149 \\
\hline F5 & 11.139 & 19 & .000 & 2.30000 & 1.8678 & 2.7322 \\
\hline F6 & 13.272 & 19 & .000 & 2.45000 & 2.0636 & 2.8364 \\
\hline
\end{tabular}




\begin{tabular}{ccccccc}
\hline F7 & 14.104 & 19 & .000 & 2.35000 & 2.0013 & 2.6987 \\
F8 & 8.059 & 19 & .000 & 2.10000 & 1.5546 & 2.6454 \\
F9 & 12.931 & 19 & .000 & 2.35000 & 1.9696 & 2.7304 \\
F10 & 3.707 & 19 & .001 & .95000 & .4137 & 1.4863 \\
\hline
\end{tabular}

* The amount of Sig. for this statistical test at the confidence level of 0.99 and $\alpha=0.01$

As the output of the statistical test shows, all identified challenges and factors of this research are affected on the impelmentation of Islamic banking. Results illustrated that the significance amounts (Sig.) are lower than 0.05 and also the calculated amount of means for all factors are higher than the test value (equal with 4: [7+1]/2). Accordingly all factors are significant and meaningful at a high level.

Then using Friedman test all factors and challenges for IB implementation have been prioritized based on the gathered data. As the previous analysis for this test statistical analysis the software SPSS was used as well. The first output indicates that Sig. is lower than 0.05 namely the Freidman test is valid and significant for ranking the challenges and factors identifies in this research. Based on the first output, the second output of this test shows the ranking of factors and challenges. The result of this test has been presented in the table 5 and 6.

Table 5. Significance results of the Friedman test.

\begin{tabular}{ccc}
\hline \multicolumn{3}{c}{ Test Statistics $^{\mathrm{a}}$} \\
\hline $\mathrm{N}$ & & 20 \\
Chi-Square & 40.290 \\
$\mathrm{df}$ & 9 \\
Asymp. Sig. & .000 \\
a. Friedman Test & \\
\hline
\end{tabular}

Table 6. Result of ranking factors and challenges using Friedman test.

\begin{tabular}{lcc}
\hline \multicolumn{1}{c}{ Identified challenges and factors } & Mean Rank & Rank \\
\hline Lack of clear rules and adequate supervision & 6.60 & 2 \\
Lack of determination at the senior executives and managers & 6.88 & 1 \\
Lack of sufficient awareness among customers and people & 5.82 & 5 \\
The lack of failure to comply with the new financial system & 4.32 & 9 \\
Lack of competitiveness with conventional banking system & 6.28 & 3 \\
Investors' risk aversion and the desire to get a fixed profit & 6.05 & 4 \\
Lack of variety for different investors' preferences & 5.27 & 7 \\
Lack of variety for different facilities applicants & 4.58 & 8 \\
Lack of appropriate solutions for banking deferred & 5.60 & 6 \\
The lack of international banking interactions & 3.20 & 10 \\
\hline
\end{tabular}


Findings based on the ranking challenges and factors related to the IB implementation showed that factor or challenge 2 (F2), namely: Lack of determination at the senior executives and managers, is the most important and factor or challenge 10 (F10), namely: The lack of international banking interactions, is the least significant from the viewpoint of the research participants. Figure 1 clearly shows the ranking results for all factors and challenges of the research.

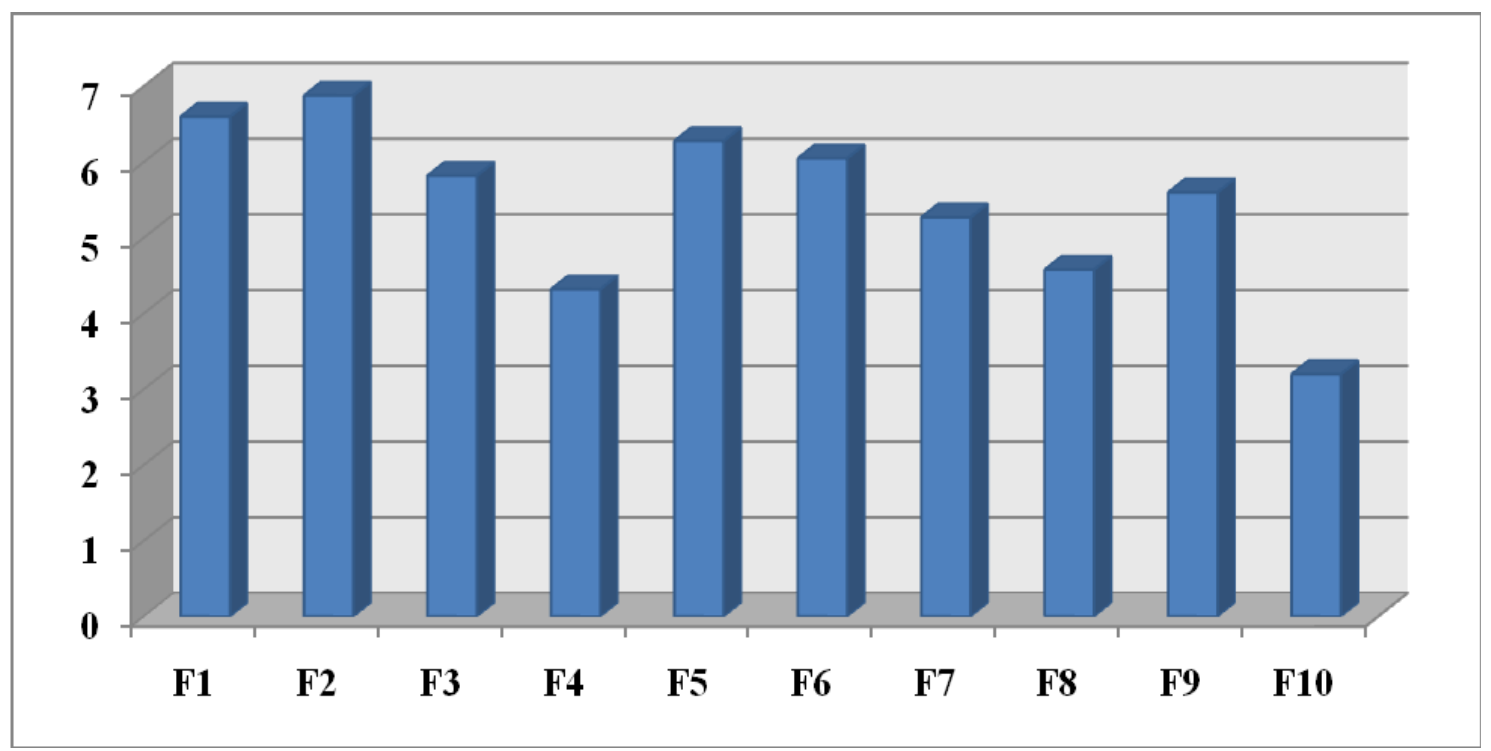

Figure 1. Results of ranking factors and challenges identifies in this research.

\section{CONCLUSIONS}

Islamic banking is currently one of the fastest growing segments of the financial market industry, operating in over 75 countries through 300 institutions (Johnson, 2013). Previous researchers believed that this system provided that completely implemented can positively effect on the economic growth and socially accepted and satisfied. Islamic banking is continuing to grow as a viable financial institution across the world (Johnson, 2013).

Islamic banking is a financial system whose key aim is to fulfil the teachings of the Holy Quran. Islamic law reflects the commands of God and this regulates all the various aspects of a Muslim's life and hence Islamic finance is directly involved with spiritual values and social justice.

The theory of Islamic banking is based on the concept that interest is strictly forbidden in Islam, and that Islamic teachings provide the required guidance on which to base the working of banks. The basic principle that has guided all theoretical work on Islamic banking is that although interest is forbidden in Islam, trade and profit is encouraged (El-Ghattis, 2011). Accordingly, complete implementing of IB is vital to reach the sustainable development in many areas of Islamic economies.

This research aimed at identify and prioritizing the important challenges regarding to the Islamic banking system in I.R.Iran. After detailed literature review and studying the previous researches, using interviews with research experts and also using convenient questionnaire required data has been gathered and then appropriate statistical analyses have been implemented and results provided. Results showed that ten basic challenged are 
associated with IB implementation that prioritizing of these challenges and factors indicated that challenge 2, Lack of determination at the senior executives and managers, was the most significant and thereafter challenge 1, Lack of clear rules and adequate supervision, secured the second priority.

Then other challenges including F5, F6, F3, F9, F7, F8, F4 and F10 gained next ranks and priorities respectively. What is so important is that all challenges identified in this research should be considered by managers and policymakers in order to achieve successful IB implementation and taking advantage of its plenty benefits.

\section{References}

[1] Abdullah, F. and Iqbal, M. (1999). Challenges Facing Islamic Banking in the $21^{\text {st }}$ Century. Proceedings of the Second Harvard University Forum on Islamic Finance, Cambridge, Massachusetts. Center for Middle Eastern Studies, Harvard University, 243-253.

[2] Akbar, S.; Shah, S.A. and Kalmadi, S. (2012). An investigation of user perceptions of Islamic banking practices in the United Kingdom. International Journal of Islamic and Middle Eastern Finance and Management, 5(4), 353-370.

[3] Chapra, M.U. (1985). Towards a Just Monetary System. Leicester: The Islamic Foundation.

[4] Chong, B.S. and Liu, M.H. (2009). Islamic banking: Interest-free or interest-based?. Pacific-Basin Finance Journal, 17, 125-144.

[5] Dadgar, Y. and Firouzan, T. (2012). Presentation a framework for determining the interest rate of exchange contracts. Quarterly Journal of Economic Research (Growth and Sustainable Development), 12 (4), 79-102.

[6] El-Ghattis, N. (2011). Islamic banking's role in economic development: future outlook. Centre of Islamic Finance, Bahrain Institute of Banking.

[7] Frost, S. M. (2004). The Bank Analyst's Handbook Money, risk and conjuring tricks. John Wiley \& Sons Ltd, England.

[8] Gerrard, P. and Cunningham, J.B. (1997). Islamic banking: a study in Singapore. International Journal of Bank Marketing, 15(6), 204-216.

[9] Gudarzi Farahani, Y. and Dastan, M. (2013). Analysis of Islamic banks' financing and economic growth: a panel co-integration approach. International Journal of Islamic and Middle Eastern Finance and Management, 6(2), 156-172.

[10] Hassan, K.M. \& Lewis M.K. (2007). Handbook of Islamic Banking. Cheltenham (UK): Edward Elgar Publishing Limited.

[11] Iqbal, M. and Molyneux, P. (2005). Thirty Years of Islamic Banking: History, Performance and Prospects. Islamic Economic, 19(1), 37-39.

[12] Iqbal, M.; Ahmad, A. and Khan, T. (1998). Challenges facing Islamic banking. Islamic Research and Training Institute of the Islamic Development Bank (IDB) publications. 
[13] Iqbal, Z. (2007). Challenges Facing Islamic Financial Industry. Journal of Islamic Economics, Banking and Finance, 3 1), 1-14.

[14] Iqbal, Z. and Mirakhor, A. (1999). Progress and Challenges of Islamic Banking. Thunderbird International Business Review, 41(4/5), 381-405.

[15] Johnson, K. (2013). The role Islamic banking in economic growth. Senior thesis in the Claremont McKenna College.

[16] Kamarulzaman, Y. and Madun, A. (2013). Marketing Islamic banking products: Malaysian perspective. Business Strategy Series, 14(2/3), 60-66.

[17] Karbhari, Y.; Naser, K. and Shahin, Z. (2004). Problems and Challenges Facing the Islamic Banking System in the West: The Case of the UK. Thunderbird International Business Review, 46(5), 521-543.

[18] Malik, M.S.; Malik, A. and Mustafa, W. (2011). Controversies that make Islamic banking controversial: An analysis of issues and challenges. American Journal of Social and Management Sciences, 2(1), 41-46.

[19] Mat Rahim, S.R. and Zakaria, R.H. (2013). Comparison on Stability between Islamic and Conventional Banks in Malaysia. Journal of Islamic Economics, Banking and Finance, 9(3), 131-149.

[20] Mirakhor, A. (2007). Islamic Finance and Globalization: A Convergence?. Journal of Islamic Economics, Banking and Finance, 3(2), 11-72.

[21] Mishkin, F. S. (2004). Economics of Money; Banking and Financial Markets. $7^{\text {th }}$ Edition. New York: Harper Collins.

[22] Mousavian, S.A. (2002). Islamic banking. Tehran: Research Institute for Monetary and Banking, Central Bank of the Islamic Republic of Iran.

[23] Shah, S.F.; Raza, M.W. and Khurshid, M.R. (2012). Islamic banking controversies and challenges. Interdisciplinary Journal of Contemporary Research in Business, 3(10), 1018-1026.

[24] Shaikh, S.A. (2013). Islamic Banking in Pakistan: A Critical Analysis. Journal of Islamic Economics, Banking and Finance, 9(2), 45-62.

[25] Siddiqi, M.N. (2006). Islamic banking and finance in theory and practice: a survey of state of the art. Islamic Economic Studies, 13(2), 1-48.

[26] Sole, J. (2008). Introducing Islamic Banks into Conventional Banking Systems. Journal of Islamic Economics, Banking and Finance, 4(2), 10-34.

[27] Talebi, M.; Kavand, M. and Hoseinpour, M. (2011). Analyzing and ranking of operational risks in Islamic Banking (Case Study: Interest Free Banking in Iran). Quarterly Journal of Islamic Economics, 11(44), 157-184.

[28] Wilson, R. (2000). Challenges and Opportunities for Islamic Banking and Finance in the West: The United Kingdom Experience. Islamic Economic Studies, 7(1/2), 35-59.

[29] Zaher, T.S. and Hassan, M.K. (2002). A Comparative Literature Survey of Islamic Finance and Banking. Financial Markets, Institutions \& Instruments, 10(4), 155-199. 
[30] M. Shoukat Malik, Muhammad Nadeem, International Letters of Social and Humanistic Sciences 10(1) (2014) 9-19.

[31] Morteza Ziaee, International Letters of Social and Humanistic Sciences 10(2) (2014) 172-180.

[32] Mohammadbagher Mohammadinejad Pashaki, Reza Tehrani, Hamid Zarea, Hossein Khanifar, Gholamreza Jandaghi, International Letters of Social and Humanistic Sciences 18 (2014) 8-13. 